\title{
Biomineralogical investigation of late-harvest grapes colonised by Botrytis cinerea Pers.
}

\author{
Marek Grabowski ${ }^{1, *}$,Maciej Pawlikowski \\ ${ }^{1}$ Department of Horticulture, Faculty of Biotechnology and Horticulture, University of Agriculture in Krakow, \\ 29 Listopada 54, 31-425 Kraków, Poland \\ ${ }^{2}$ Department of Mineralogy, Petrography and Geochemistry, Faculty of Geology, Geophysics and Environmental Protection, \\ AGH University of Science and Technology, Mickiewicza 30, 30-059 Kraków, Poland
}

\begin{abstract}
The ripening process of two grape varieties in the vineyard located in the Sandomierz region was examined. In 2015, the 'Regent' and the 'Sibera' varieties reached physiological ripeness on $30^{\text {th }}$ September and $3^{\text {rd }}$ October, respectively. On both harvest dates, in addition to soluble solids content, titratable acidity, and $\mathrm{pH}$, the macronutrient content was also determined. In the phase of physiological ripeness, the 'Sibera' variety showed higher acidity $\left(1.02 \mathrm{~g} \cdot 100 \mathrm{~mL}^{-1}\right)$ compared with the 'Regent' $\left(0.87 \mathrm{~g} \cdot 100 \mathrm{~mL}^{-1}\right)$. A higher soluble solids content was found in the 'Regent' $\left(20.4^{\circ} \mathrm{Brix}\right)$, and slightly lower in the 'Sibera' $\left(18.1^{\circ}\right.$ Brix). The must of the 'Regent' had a higher $\mathrm{pH}$ (3.5). This variety also had higher macronutrient contents $(\mathrm{K}, \mathrm{Ca}$ and $\mathrm{Mg}$ ). Grapes harvested after 3 weeks (late harvest) showed higher values of sugars, $\mathrm{pH}, \mathrm{K}$, and $\mathrm{P}$ for both varieties. However, their titratable acidity content, and $\mathrm{Ca}$ and $\mathrm{Mg}$ contents decreased. Microscopic examination showed differences in mycelial growth of Botrytis cinerea on grape bunches for both of the varieties left for the late harvest. The mycelial growth promoted faster dehydration of the 'Sibera' berries. Spot chemical analyses of 'Sibera' berry peel performed using EDS (energy dispersive spectroscopy) showed the occurrence of elevated contents of potassium, phosphorus, sulphur, magnesium and silicon. Around skin cracks, sugar crystals as well as hardto-identify microcrystals were formed containing potassium. On the surface of the 'Regent' berries, potassium, and traces of phosphorus, silicon, magnesium, sulphur and calcium were found.
\end{abstract}

Keywords: Botrytis cinerea, grapes, harvest, minerals, ripeness, 'Regent' variety, 'Sibera' variety

\section{INTRODUCTION}

In viticulture, it is particularly important to know the ripening processes of the grapes and to work out the right date for harvesting the varieties cultivated in the particular micro-regions (Santos et al., 2012; IzajaszParchańska et al., 2014). Adequate ripeness and optimum harvest time are the most important factors determining the quality of future wine (Orduna, 2010). The main indicator of fruit ripeness is the appropriate level of sugar and organic acid contents in the must, and the $\mathrm{pH}$.

Poland has been classified in the so-called winegrowing zone A in Europe, often referred to as 'coolclimate' wine-growing region. Despite global warming, the conditions for viticulture in Poland are much more difficult than in regions with longer wine-growing traditions (Kopeć, 2009; Schulz and Jones, 2010).

Due to cool-climate and habitat conditions, the grapes harvested are characterised by lower sugar content (18-23\%), which is associated with a low alcohol level and higher titratable acidity (Tarko et al., 2008). This has certain advantages that are manifested by a better balance between the sugar and the organic acid content, the $\mathrm{pH}$ value and a higher accumulation of certain aromatic compounds, which allows the production of wines of good quality (Keller, 2010). 
As the grapes ripen, their acidity decreases, which is associated with a change in the ratio between the individual acids. The sugar content then increases very slowly while the acidity decreases very significantly. The most important dry matter component of the ripe fruit is sugar the content of which may be even higher in overripe and dried berries and those covered with Botrytis cinerea (Fournier et al., 2013; Gubler et al., 2013). The chemical composition of the must depends on the course of weather conditions in the individual seasons, habitat conditions (location of the vineyard and the soil), varietal distribution and the agricultural methods utilised (Pachnowska and Ochmian, 2018). The determinants of the quality of the must are organic acids, mainly malic acid and tartaric acid (Sluys, 2006). In years with unfavourable weather conditions during the ripening period (low temperatures, low sunshine), the level of malic acid is much higher and reaches $1.5-1.6 \mathrm{~g} \cdot 100 \mathrm{~mL}^{-1}$ compared to the typical concentrations of $0.2-0.65 \mathrm{~g} \cdot 100 \mathrm{~mL}^{-1}$.

In Polish conditions, tartaric acid is most commonly found in quantities in the range of $0.5-1.0 \mathrm{~g} \cdot 100 \mathrm{~mL}^{-1}$. In a cool climate zone, there is no risk of malic acid levels dropping too low, which might result in a loss of freshness in the wine. However, a late harvest is recommended to reduce its content (weather conditions permitting) even after obtaining a sufficient level of sugar. The term 'late harvest' not only implies harvesting of overripe grapes, but it also refers to infestation by $B$. cinerea that is referred to as botrytisation or noble rot (Lorenzini et al., 2012; Negri et al., 2017; Simonato et al., 2019). Late harvest causes an increase in sugar content in the berries while reducing the acidity level. The density of the must also increases, and the wines produced are more extractive. The $\mathrm{pH}$ of the must depends on the concentration and degree of dissociation of the acids present, and should be between 2.9 and 3.5. It should, however, be remembered that longer ripening is not possible in every season due to the rapid spread of grey mould. Long-lasting precipitation events cause berry cracking, which promotes infestation by $B$. cinerea. The hyphae penetrate the berry skin and cause the fruits to rot and decay. In favourable weather conditions (warm and dry autumn) when the berries contain more than $20 \%$ of sugars, the fungus damages the berry skin enzymatically but does not penetrate the pulp. This contributes to faster water loss and wrinkling of the berries. This phenomenon is called the noble rot, and it is only sporadically found in the Polish climate zone and only concerns certain white grape varieties. The loss of water from the berries leads to the concentration of sugar and other constituents. The activity of $B$. cinerea causes certain changes in the berries, which enable vintners to produce unique sweet white wines. The quantity of wine produced is relatively small, but its quality is high. Some important grape-must components are minerals that constitute 2-5 g · $\mathrm{L}^{-1}$ (Pereira et al., 2006; Bertoldi et al., 2011). Differentiation is observed here depending on the variety, agricultural methods and habitat conditions. Their level is reduced during vinification.

\section{MATERIALS AND METHODS}

The material for the tests came from the 8-year-old vines growing in the Zdanów vineyard near Sandomierz. The investigation used fruits of two varieties of interspecific hybrids: white-skinned 'Sibera' (Saperavi Siewiernyj $) \times($ Foster White Seedling $\times$ Prachttraube $)$ and dark-skinned 'Regent' - non-specific hybrid (Diana $\times$ Chambourcin).

From the beginning of September, the main parameters of grape maturity were monitored. Once a week, 10 bunches were collected from different parts of the vineyard. Must was extracted from them and the ripeness of the fruit and the date of harvest were determined. The main indicators of technological maturity were:

- soluble solids content ( ${ }^{\circ}$ Brix) using an Index Instruments Ltd DR-103 L refractometer

_ titratable acidity $\left(\mathrm{g} \cdot 100 \mathrm{~mL}^{-1}\right)$ (expressed as tartaric acid) - by potentiometric method

- $\mathrm{pH}$ - by titration.

A portion of both cultivars was harvested at the stage of physiological ripeness, which was reached by the 'Sibera' variety reached on $3^{\text {rd }}$ October and by the 'Regent' variety on $30^{\text {th }}$ September. The other half of the area with the above-mentioned varieties was used for the so-called late harvest, which was carried out 3 weeks later. In addition to the soluble solids content, titratable acidity and $\mathrm{pH}$, the contents of selected macronutrients (potassium, phosphorus, calcium and magnesium) were also determined. Calcium and magnesium were measured by atomic absorption spectrometry (AAS). For potassium, atomic emission spectrophotometry was used. Phosphorus was determined by the colorimetric method on a spectrophotometer. Juice analyses were performed during physiological ripeness and after 3 weeks (late harvest). The results were expressed in $\mathrm{mg} \cdot \mathrm{L}^{-1}$. At the moment when mycelium and spores of $B$. cinerea Pers. appeared on the berries, preliminary tests and observations were commenced using a binocular magnifier L 20. During the evaluation of berries, $100 \times$ magnification was used and photomicrographs of the objects observed were taken. Basic chemical observations and analyses on overripe and drying berries were made using a field-emission scanning electron microscope (Quanta $200 \mathrm{FEG}$ ) in low vacuum mode at $10 \mathrm{kV}$ cathode voltage (the photos of the 'Regent' were taken at $12.5 \mathrm{kV}$ ). The spot chemical analyses using EDS (energy dispersive spectroscopy) were qualitative. The results of the individual tests have been compiled in the form of photographs and graphs. To confirm the presence of $B$. cinerea, samples were collected from the dried grapes, and after rinsing in distilled water and 98\% ethyl alcohol, they were placed on PDA (potato dextrose agar) medium where $85 \mathrm{~B}$. cinerea isolates were obtained. At the same time, the investigation was carried out concerning the growth of $B$. cinerea and the concomitant biomineralogical processes. 


\section{RESULTS AND DISCUSSION}

Monitoring of the main grape maturity parameters carried out from the beginning of September showed different rates of changes in the varieties investigated. Sugar content in the individual varieties increased systematically and only slowed down significantly towards the end of the ripening period. Titratable acidity decreased slowly showing variance between the varieties (Kuhn et al., 2014; Gąstoł, 2015). Higher acidity at physiological ripeness was found for the 'Sibera' $\left(1.02 \mathrm{~g} \cdot 100 \mathrm{~mL}^{-1}\right)$ whereas the 'Regent' variety had lower acidity $\left(0.87 \mathrm{~g} \cdot 100 \mathrm{~mL}^{-1}\right)$. On the other hand, this variety had higher extract content (20.4\%) compared with the 'Sibera' (18.1\%). Also, a higher $\mathrm{pH}$ was found in the 'Regent' variety (3.5). Higher content of macronutrients $(\mathrm{K}, \mathrm{Ca}$ and $\mathrm{Mg}$ ) was also found in the must of this variety. Only phosphorus content was slightly higher in the 'Sibera' variety. After 3 weeks (late harvest), both cultivars showed an increase in all the parameters measured, except for $\mathrm{Ca}$ and $\mathrm{Mg}$ contents and titratable acidity where this value decreased (Table 1). After 2 weeks, mycelium and spores of $B$. cinerea appeared on the late-harvest grapes. At that time, tests were commenced on overripe and drying bunches colonised by the fungus, and an examination of the biomineralogical phenomena accompanying this process.

Preliminary observations carried out on the lateharvested 'Sibera' showed a widespread occurrence of $B$. cinerea mycelium on the surface of wrinkled berries before harvesting. The binocular magnifying glass test confirmed the presence of mycelial hyphae not only on the surface of the wrinkled berry skin but also at skin lesions and cracks (Figure 1A-D). Particularly

Table 1. Basic aggregate parameters and contents of selected macronutrients in 'Sibera' and 'Regent' grape varieties

\begin{tabular}{|c|c|c|c|c|c|c|c|}
\hline Stage of fruit maturation & $\begin{array}{l}\text { Soluble solids } \\
\text { content }\left({ }^{\circ} \text { Brix }\right)\end{array}$ & $\begin{array}{l}\text { Titratable acidity } \\
\left(\mathrm{g} \cdot 100 \mathrm{~mL}^{-1}\right)\end{array}$ & $\mathrm{pH}$ & $\begin{array}{c}\mathrm{K} \\
\left(\mathrm{mg} \cdot \mathrm{L}^{-1}\right)\end{array}$ & $\begin{array}{c}\mathrm{P} \\
\left(\mathrm{mg} \cdot \mathrm{L}^{-1}\right)\end{array}$ & $\begin{array}{c}\mathrm{Ca} \\
\left(\mathrm{mg} \cdot \mathrm{L}^{-1}\right)\end{array}$ & $\begin{array}{c}\mathrm{Mg} \\
\left(\mathrm{mg} \cdot \mathrm{L}^{-1}\right)\end{array}$ \\
\hline \multicolumn{8}{|l|}{ 'Sibera' } \\
\hline Physiological ripeness** & $18.1 \mathrm{a}^{*}$ & $1.02 \mathrm{~b}$ & $3.0 \mathrm{a}$ & $865 \mathrm{a}$ & $215 \mathrm{a}$ & $91 \mathrm{a}$ & $85 \mathrm{~b}$ \\
\hline Late harvest & $21.4 \mathrm{~b}$ & $0.85 \mathrm{a}$ & $3.4 \mathrm{~b}$ & $938 \mathrm{~b}$ & $237 \mathrm{~b}$ & $88 \mathrm{a}$ & $72 \mathrm{a}$ \\
\hline \multicolumn{8}{|l|}{ 'Regent' } \\
\hline Physiological ripeness & $20.4 \mathrm{a}$ & $0.87 \mathrm{~b}$ & $3.5 \mathrm{a}$ & $1512 \mathrm{a}$ & $191 \mathrm{a}$ & $121 \mathrm{a}$ & 93 a \\
\hline Late harvest & $24.3 \mathrm{~b}$ & $0.75 \mathrm{a}$ & $3.7 \mathrm{~b}$ & $1610 \mathrm{~b}$ & $223 \mathrm{~b}$ & $119 \mathrm{a}$ & $89 a$ \\
\hline
\end{tabular}

*Means followed by the same letter within columns among cultivars do not differ significantly at $p \leq 0.05$ by Duncan test.

**Harvest dates: 'Sibera' - physiological ripeness (3 October), late harvest (24 October); 'Regent' - physiological ripeness (30 September), late harvest (20 October).

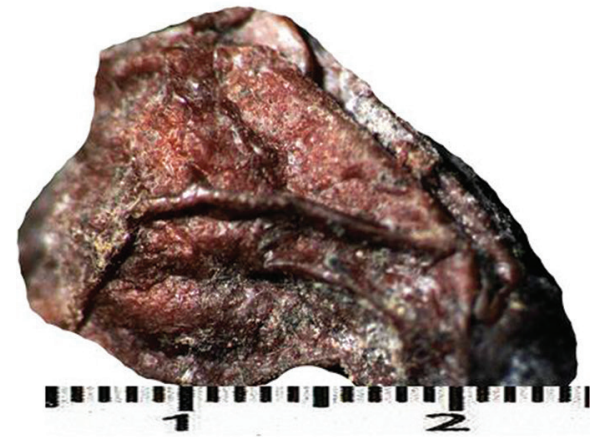

A

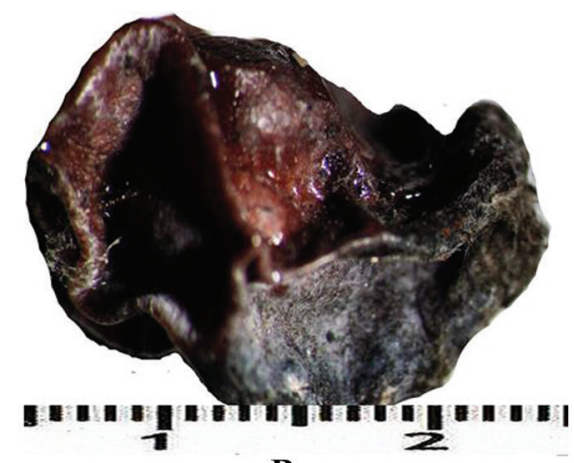

B

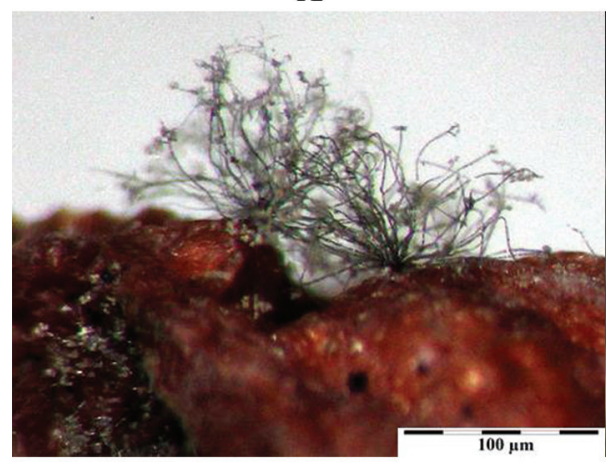

C

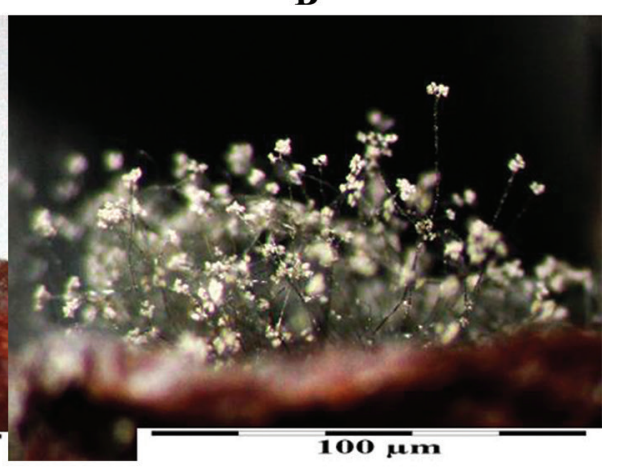

D

Figure 1. 'Sibera' variety. (A) Dried berry covered with a red growth. (B) Drying berry with sticky pink juice concentrated in morphological concavities. (C) Clusters of mycelial hyphae on the surface of the drying bunch at a skin rupture. (D) Abundant sporulation of $B$. cinerea on the surface a drying berry. Photomicrographs were taken with a binocular magnifier. 
rapid mycelial growth and abundant sporulation of the pathogen were observed at the sites of skin cracks. At the same time, no development of the rotting process was observed in the berry flesh covered with grey mycelium. In the more dried-out bunches, some of the berries were covered with a pink coating that remained after the dried juice (Hegyi-Kalo et al., 2019). SEM observations revealed the exact details of the mycelial growth of $B$. cinerea. Numerous natural cracks were found on the surface of the berry skin, with clusters of mycelial hyphae and colloidal spores around them (Figure 2A-D). EDS spot chemical analyses of dried and wrinkled berry skin of the 'Sibera' showed the presence on its surface of increased contents of potassium, phosphorus, sulphur, magnesium and silicon (Figure $3 \mathrm{~A}$ and $\mathrm{B}$ ). A comparison of the EDS spectra acquired from cracked berries (Figure 3C - red spectrum) with the spectra acquired from skin without lesions (Figure $3 \mathrm{C}$ - blue spectrum) shows a clear increase in the content of the elements determined on the surface of the somewhat dried out and cracked berries. When examining bunches of the 'Regent' with symptoms of grey mould, some differences in mycelial growth and the destructive effect of the pathogen on overripe bunches were found. A faster rate of mycelial growth around the skin lesion was observed. The mycelium was more abundant in the tightly compacted clusters forming abundant air growth on the surface around the lesions on the skin (Vail and Marios, 1991). The most frequently observed lesions at the places of mycelium occurrence were the processes of berry flesh rotting. Abundant mycelial growth and conidial spores were most often found in places where the surface of the berries in the bunch was covered with juice or sugar crystals (Figure 4A and B). Observations of the places where the stalk and berries come into contact with each other in the bunch were also interesting (Figure 4C). Already at low magnifications, the concentration of red dyes associated with the mineralisation of organic compounds containing iron was visible. Mineralisation of sugars often occurred within the stalk (Figure 4D). Their presence in this place promotes easy separation of berries from the bunch. Further morphological details of the development of $B$. cinerea on grape bunches

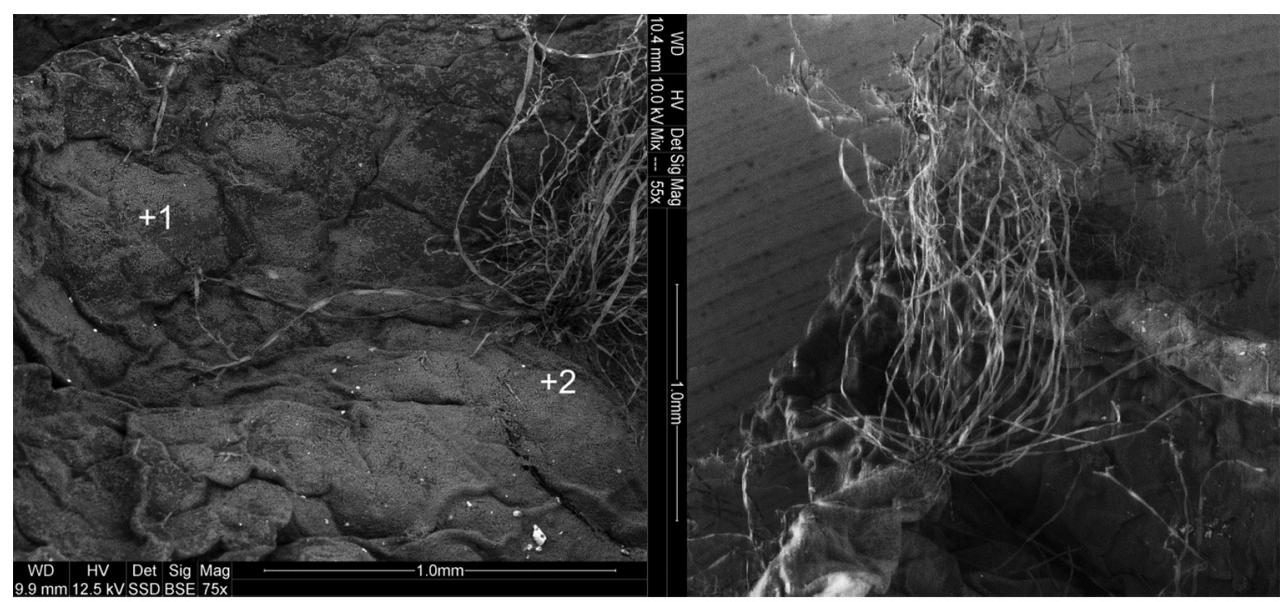

A

B

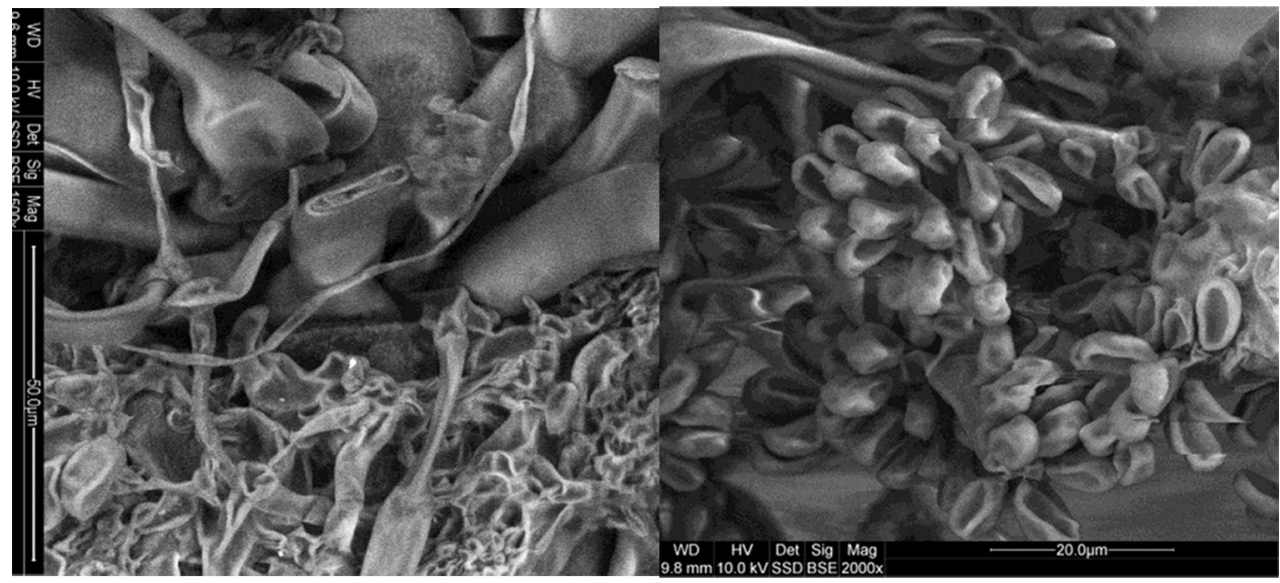

C D

Figure 2. (A) Cracks in the skin of a drying berry; $+1,+2-$ EDS analysis locations. (B) mycelial hyphae on the edge of a skin crack. (C) - A cluster of mycelial hyphae and a cross section of a single hypha. (D) Conidia of $B$. cinerea. Scanning microscope, scale magnification. 

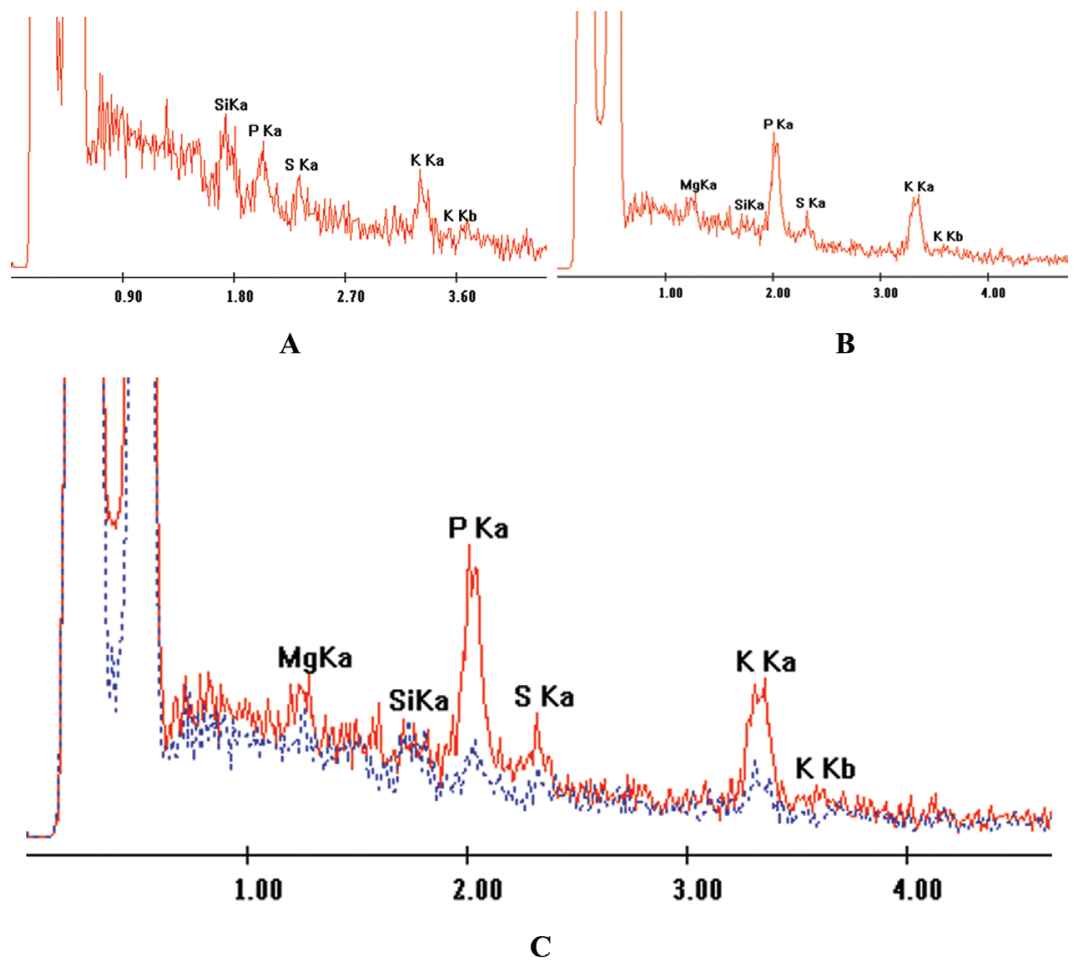

Figure 3. EDS energy spectra of the skin surface of drying berries of the 'Sibera' variety at spots $+1(\mathrm{~A})$ and +2 (B) shown in Figures 2A and 3C. EDS energy spectra obtained from the surface of the 'Sibera' variety grapes. Dried and cracked berries - red spectrum. Undamaged berries, less dry - blue spectrum.

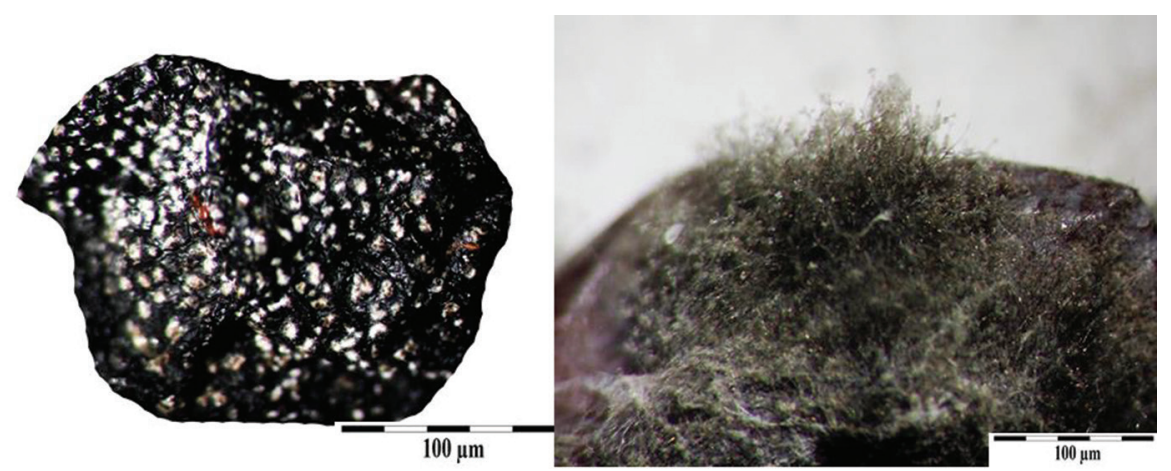

A

B

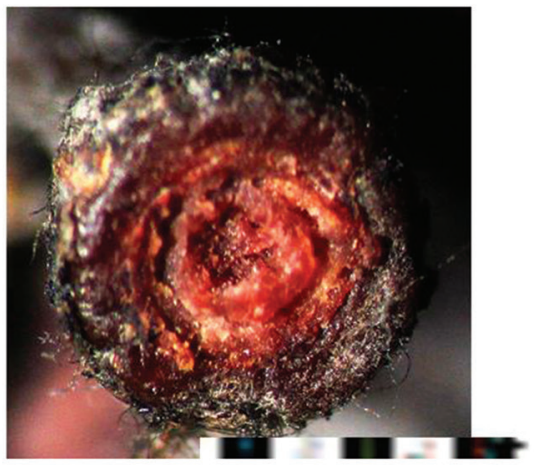

C

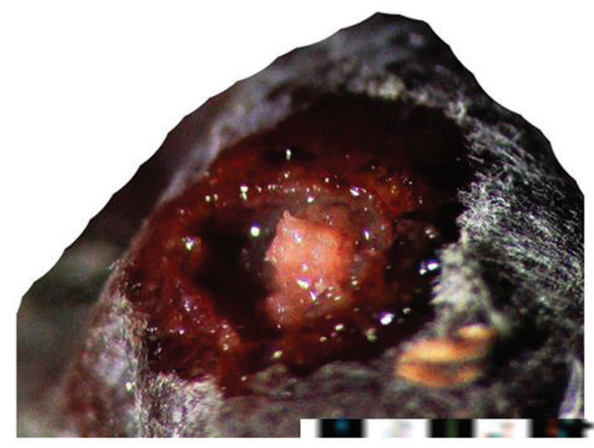

D

Figure 4. 'Regent' variety. (A) The surface of a drying berry covered with bright crystals of a potassium compound. (B) Abundant growth of $B$. cinerea air mycelium at a rupture of the peel of a 'Regent' berry. (C) Stalk with advancing mineralisation by red organic iron compounds. (D) Mineralisation by sugars at the location of a detached peduncle; visible glossy sugar microcrystals. Photomicrographs taken with a binocular magnifier. 


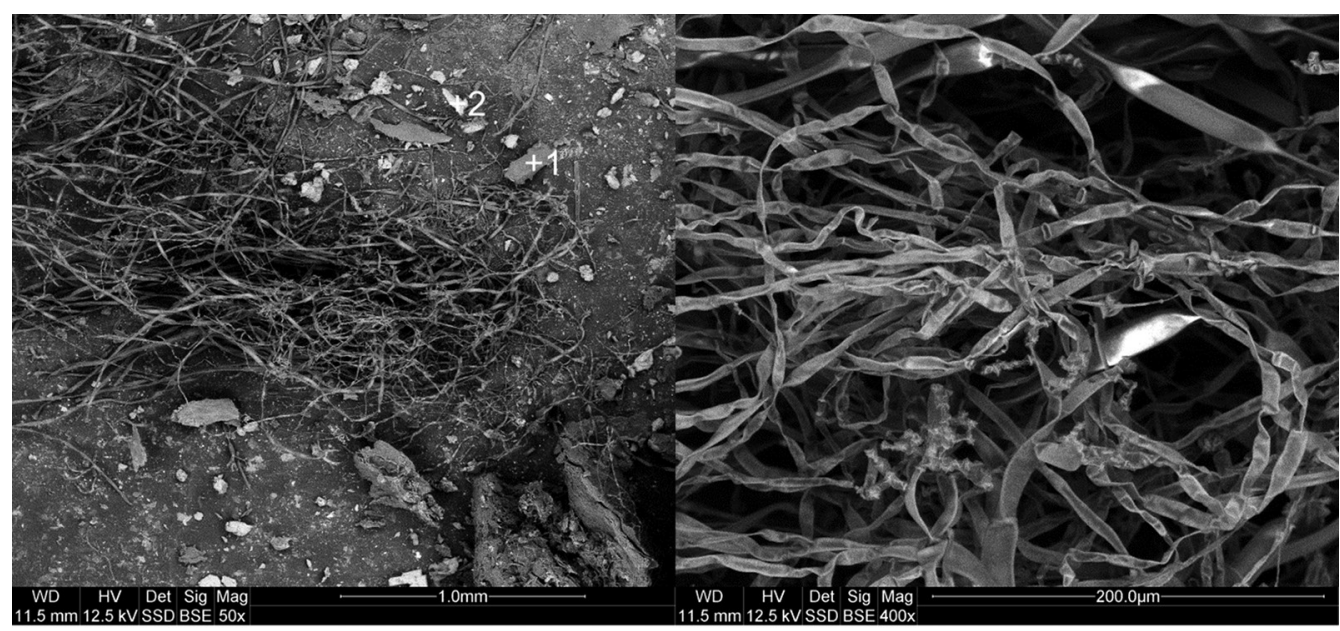

A

B

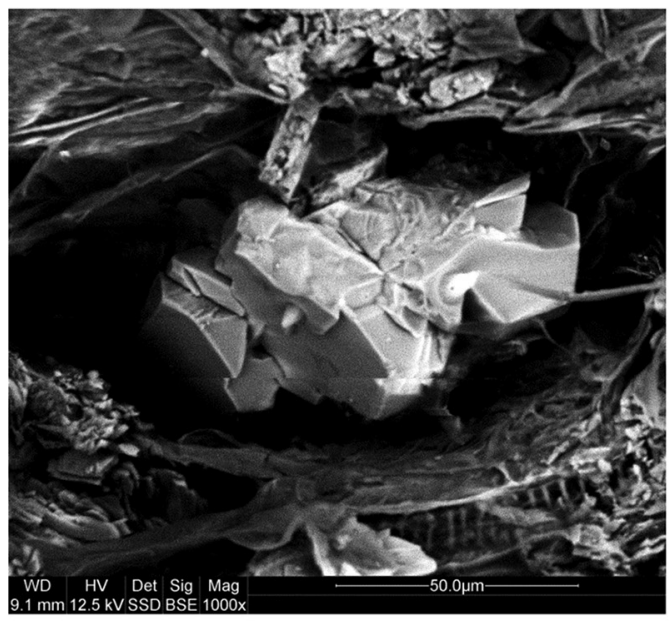

C

Figure 5. Surface of ripe 'Regent' berries. (A) B. cinerea mycelium at the location of sugar microcrystals and potassium compounds. $+1,+2$ - EDS analysis locations. (B) Mycelial hyphae located within skin cracks. (C) A crystal of an organic compound containing potassium, located in the wound cavity caused by berry skin cracking.

of the 'Regent' were provided by SEM observations. It follows that the fungus develops on the surface of berries only in places of skin lesions around which sugar crystals form as well as difficult to identify microcrystals containing potassium (Figure 5A). Chemical analyses (EDS) confirmed that the bright crystals covering drying grape berries are organic potassium compounds (Figure 5B and 5C). Detailed examination of sugar crystals collected from the surface of the 'Regent' grapevine grapes indicates the presence of a small amount of potassium accompanied by traces of phosphorus, silicon, magnesium, sulphur and calcium (Figure $6 \mathrm{~A}-\mathrm{C}$ ). Their presence may be associated with the fact that grapes are covered with a thin layer of mineral dust. Based on the tests performed, it can be concluded that the levels of sugars increased in the tested varieties left for late harvest, which is extremely important for the production of high-quality wines, especially sweet wines (Magyar and Benz, 2006; Bindon et al., 2013). Both varieties received high scores about the technological factors that were tested although Poland belongs to the cool climate zone. The minerals present on the surface of overripe berries fully reflect the content of the macronutrients examined in the must (Bertoldi et al., 2011; Miele et al., 2015). They penetrated with water and sugars through the berry skins crystallising on their surface. This is particularly true of potassium and phosphorus, which make the largest proportion of all minerals present in the must (Butzke and Boulton, 1997; Cozzolino, 2015; Rogiers et al., 2017). Skin lesions associated with the presence of $B$. cinerea mycelium increased the content of certain elements present on overripe fruit. Interestingly, decreases in calcium and magnesium contents in the overripe fruit were observed where the formation of the salt in organic acids occurs. The fungus $B$. cinerea plays a positive role in the process of ripening and drying of berries, which is visible in the 'Sibera', having a delicate and thin skin. Weather monitoring showed that in the 2015 season, the sum of active temperatures 

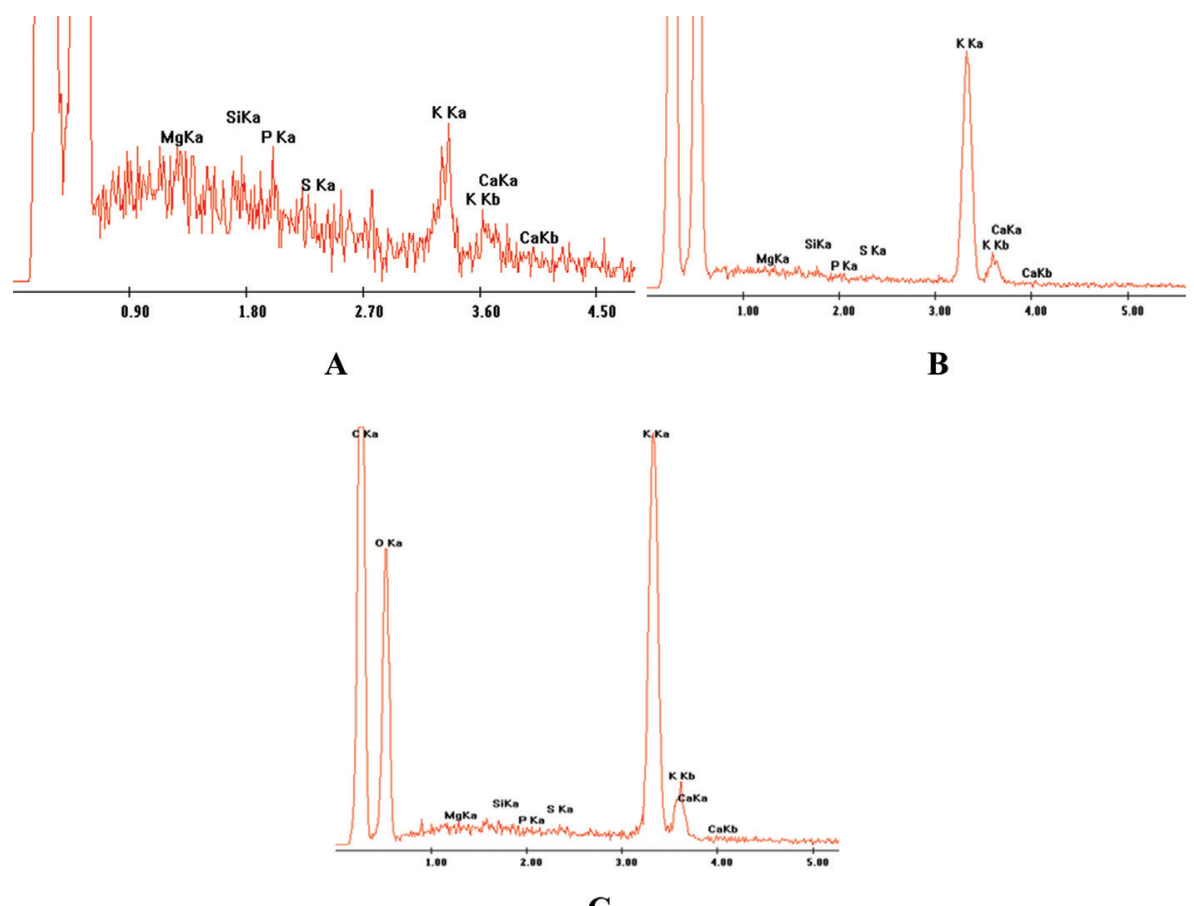

C

Figure 6. EDS energy spectra obtained from the surface of the 'Regent' variety grapes. at points +1 (A), +2 (B) shown in Figure 5A and the crystal (C) shown in Figure 5C.

(SAT) was $2950^{\circ} \mathrm{C}$, while the latitude temperature index (LTI) was 246. The indicators also provided favourable conditions for ripening, even for the varieties with very late ripening. This makes it easier, under favourable weather conditions, for $B$. cinerea to grow on the surface of overripe berries causing them to dry out, which is associated, under favourable weather conditions (sunny days, wet nights), with the phenomenon of "noble

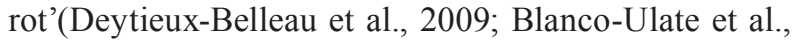
2015; Carabajal-Ida et al., 2016).

\section{CONCLUSIONS}

1. The varieties tested reached, at the stage of physiological ripeness, satisfactory technological parameters for the must at a level sufficient to produce dry and semi-dry wines.

2. The grapes left for late harvest had higher soluble solids content and higher $\mathrm{pH}$. Titratable acidity, on the other hand, decreased. The late-harvest grape must had higher potassium and phosphorus contents. Calcium and magnesium contents were lower.

3. B. cinerea mycelium growing on the surface of the 'Sibera' berries caused faster drying and wrinkling of the berry skin. The 'Regent' grapes covered with $B$. cinerea mycelium displayed a progressive rotting process of the berries.

4. The 'Sibera' variety of berries was found to have elevated potassium, phosphorus, sulphur, magnesium and silicon contents. Crystals of sugars indicating the presence of potassium, phosphorus, silicon, magnesium, sulphur and calcium were found on the 'Regent' berries.

\section{FUNDING}

This research was financed by the Ministry of Science and Higher Education of the Republic of Poland DS 3508/KSiP.

\section{AUTHOR CONTRIBUTIONS}

M.G. designed and performed experiments, analysed data and corrected the manuscript. M.P. designed and performed experiments and gave suggestions.

\section{CONFLICT OF INTEREST}

The authors declare no conflict of interest.

\section{REFERENCES}

Bertoldi, D., Larcher, R., Bertamini, M., Otto, S., Concheri, G., And Nicolini, G. (2011). Acumulation and distribution pattern of macro- and microelements and trace elements in Vitis vinifera $\mathrm{cv}$. Chardonnay berries. Journal of Agricultural and Food Chemistry, 59(13), 7224-7236.

Bindon, K., Varela, C., Kennedy, J., Holt, H., and Herderich, M. (2013). Relationships between harvest time and wine composition. Vitis vinifera cv. Cabernet Sauvignon grapes. Grape and wine chemistry. Food Chemistry, 138(2), 1696-1705.

Blanco-Ulate, B., Amrine, K. C., Collins, T. S., Rivero, R. M., Vincente, A. R., Morales-Cruz, A., Doyle, C. L., Ye, Z., Allen, G., Heymann, H., Ebeler, S. E., ANd CANTu, D. (2015). Developmental and metabolic plasticity of white-skinned grape 
berries in response to Botrytis cinerea during noble rot. Plant Physiology, 169, 2422-2443.

Butzke, C. E., And Boulton, B. E. (1997). Acidity, pH and potassium for grape growers. Practical Winery and Vineyard, 18, 10-16.

Carabajal-Ida, D., Maury, C., Salas, E., Siret, R., And Mehinagic, E. (2016). Physico-chemical properties of botrytised Chenin blanc grapes to assess the extent of noble rot. European Food Research and Technology, 242, 117-126.

Cozzolino, D. (2015). Elemental composition in grapes and wine. In M. de la Guardia and S. Garrigues (Eds), Handbook of mineral elements in Food (pp. 473-487). Chichester, UK: John Wiley \& Sons, Ltd.

Deytieux-Belleau, C., Geny, L., Roudet, J., Doneche, B., And Fermaud, M. (2009). Grape berry skin features related to ontogenic resistance to Botrytis cinerea. European Journal of Plant Pathology, 125, 551-563.

Fournier, E., Gladieux, P., and Giraud, T. (2013). The "Dr Jekyll and MR Hyde fungus": Noble rot versus gray mold symptoms of Botrytis cinerea on grapes. Evolutionary Applications, 6(6), 960-969.

GĄstOŁ, M. (2015). Vineyard performance and fruit quality of some interspecific grapevine cultivars in cool climate conditions. Folia Horticulturae, 27(1), 21-31.

Gubler, W. D., Hashim, J. M., Smilanick, J. L., And Leavitt, G. M. (2013). Gray mold (Botrytis cinerea). Grape Pest Management UCANR, 3343, 133-136.

Hegyi-Kalo, J., Holb, J., Lengyel, S., Juhasz, A., And VACZY, K. Z. (2019). Effect of year, sampling month and grape cultivar on noble rot incidence, mycelial growth rate and morphological type of Botrytis cinerea during noble rot development. European Journal of Plant Pathology, 155(1), 339-348.

Izajasz-PARchańska, M., Cioch, M., And Tuszyński, T. (2014). Monitoring parametrów dojrzałości technologicznej winogron na terenie małopolskiej Winnicy Srebrna Góra, w sezonie wegetacyjnym 2012. [Monitoring parameters of technological maturity of grapes in malopolska Silver Mountain Vineyard in the growing season 2012] Acta Agrophysica, 21(3), 263-278.

Keller, M. (2010). The science of grapevines. Anatomy and physiology. Burlington, VT: Academic Press.

Kopeć, B. (2009). Uwarunkowania termiczne wegetacji winorośli na obszarze południowo-wschodniej Polski. [Thermal conditions of grapes vegetation in south-eastern Poland]. Infrastruktura $i$ Ekologia Terenów Wiejskich, 4, 251-262.

Kuhn, N., Guan, L., Dai, Z. W., Wu, B. H., Laubergeat, V., Gormes, E., Li, S. H., Godoy, F., Arce-Johnson, P., ANd DeLrot, S. (2014). Berry ripening: Recently heard through the grapevine. Journal of Experimental Botany, 65(16), 4543-4559.

Lorenzini, M., Azzolini, M., Tosi, E., And Zapparoli, G. (2012). Postharvest grape infection of Botrytis cinerea and its interactions with other moulds under withering conditions to produce noble-rotten grapes. Journal of Applied Microbiology, 114, 762-770.
Magyar, I., And Benz, Z. (2006). Morphological and taxonomic study on mycobionte of noble rotted grapes in the Tokaji wine district. Acta Alimentaria, $35,237-246$.

Miele, A., Rizzon, L. A., Queiroz, S. C., And Gianello, C. (2015). Physicochemical composition, minerals, and pesticide residues in organic grape juices. Food Science and Technology (Campinas), 35(1), 120-126.

Negri, S.,Lovato,A.,Boscaini,F., Salvetti,E., Toriani, S., Commisso, M., Danzi, R., Ugliano, M., Polverari, A., Tornieli, G., AND Guzzo, F. (2017). The induction of noble rot (Botrytis cinerea) infection during postharvest withering changes the metabolome of grapevine berries (Vitis vinifera L., cv. Garganega). Frontiers in Plant Science, 8, 1002, doi: 10.3389/ fpls.2017.01002.

OrdunA, R. M. (2010). Climate change associated effects on grape and wine quality and production. Food Research International, 43(7), 1844-1855.

Pachnowska, K., And Ochmian, I. (2018). Cane pruning intensity of vine as a substantial factor influencing physico-chemical attributes of berries cultivar 'Regent'. Folia Pomeranae Universitatis Technologiae Stetinensis, Agricultura, Alimentaria, Piscaria et Zootechnica, 343(47)3, 43-54.

Pereira, G. E., Gandillere, J. P., Pieri, P., Hilbert, G., Mancurt, M., Deborade, C., Moing, A., And Rolin, D. (2006). Microclimate influence on mineral and metabolic profiles of grape berries. Journal of Agricultural and Food Chemistry, 54(18), 6765-6775.

Rogiers, S. Y., Coetzee, Z. A., Walker, R. R., Deloire, A., And Tyerman, S. D. (2017). Potassium in the grape (Vitis vinifera) berry: Transport and function. Frontiers in Plant Science, 8, 1629, doi: 10.3389/ fpls.2017.01629.

Santos, A. O., Wample, R. J., Sachidhanatham, S., AND Kaye, O. (2012). Grape quality mapping for vinegard differential harvesting. Brazilian Archives of Biology and Technology, 55(2), 193-204.

Schulz, H. R., AND Jones, G. V. (2010). Climate induced historic and future changes in viticulture. Journal of Wine Research, 21, 137-145.

Simonato, B., Lorenzini, M., Capriani, M., Finato, F., And Zapparoli, G. (2019). Correlating noble rot infection of Garganega withered grapes with key molecules and odorants of botrytised passito wine. Foods, 8(12), 642.

SLuYs, S. L. (2006). Climatic influences on the grapevine: A study of viticulture in the Waipara Basin. Christchurch, New Zealand: University of Canterbury.

Tarko, T., Duda-Chodak, A., Sroka, P., SAtora, P., AND Jurasz, E. (2008). Physicochemical and antioxidant properties of selected Polish grape and fruit wines. Acta Scientiarum Polonorum, Hortorum Cultus, 7(3), 35-45.

VAil, M., AND Marios, J. (1991). Grape cluster architecture and the susceptibility of berries to Botrytis cinerea. Phytopathology, 81, 188-191.

Received: March 10, 2020; accepted: August 14, 2020. 